\title{
Correlation between Depression and Anxiety in Patients with Chronic Non- Malignant Pain
}

1,4 Irena Kovačević

2 Valentina Krikšić

1 Štefanija Ozimec Vulinec

3 Adriano Friganović

1 Boris llić

1 Sanja Ledinski Fičko

1 University of Applied Health Sciences, Zagreb, Croatia

2 Institution for Home Health Care „Domnius", Zagreb, Croatia

${ }^{3}$ University Hospital Centre Zagreb, Zagreb, Croatia

4 University of Ljubljana, Faculty of Medicine, Ljubljana, Slovenia

Article received: 18.03.2021.

Article accepted: 12.04.2021.

Author for correspondence:

Irena Kovačević

University of Applied Health Sciences

Mlinarska 38, Zagreb, Croatia

E-mail: irena.kovacevic@zvu.hr

https://doi.org/10.24141/2/5/1/8

Keywords: depression, anxiety, chronic non-malignant pain, ethnicity, primary health care

\section{Abstract}

Introduction. Two-thirds of primary care patients with depression also have somatic symptoms present, making detection of depression more difficult. Primary health care is the first level of screening for depression, and early detection is key to treatment success. Anxiety also has a high comorbidity rate with chronic pain conditions. Generalized anxiety disorder (GAD) is common among patients with "medically unexplained" chronic pain and chronic physical illness and is also a predictor of chronic musculoskeletal pain after trauma. Belonging to different ethnic groups and ignorance of these differences by primary care physicians can be an obstacle to good health care, especially early recognition of depressive symptoms.

Aim. The aim of this proposed, systematic work was to draw conclusions from empirical research dealing with the processes involved in the examination of depression, anxiety, and chronic non-malignant pain. The research question for this review paper was to examine the correlation of depression and anxiety with chronic non-malignant pain. The aim was to examine the role of primary health care in recognizing, preventing, and treating depression and anxiety in patients with chronic non-malignant pain, and whether there is a difference in the correlation between depression, anxiety, and chronic non-malignant pain according to ethnicity.

Methods. Methods for identifying the study were derived from the Medline database (via PubMed). 
The analysis included all scientific papers in English, regardless of methodology, published since 2011. The papers dealt with the correlation between depression, anxiety, and chronic non-malignant pain, and included the population of primary care patients over 18 years of age who suffer from chronic nonmalignant pain and at the same time have symptoms of depression and anxiety present or are members of ethnic groups. 403 articles were found, original and review papers, of which, after a detailed reading, 10 were selected that meet the inclusion criteria for the purposes of this review.

Results. Depression and anxiety are significantly more present in people with chronic pain (23\%), compared to those who do not have chronic pain $(12 \%)$. The most common is chronic musculoskeletal pain, with one-third of patients having depression. Depression and anxiety are significantly associated with the intensity and duration of pain. Chronic pain and depression also differ according to ethnic groups, with cultural differences and language barriers being a barrier to early detection of depression.

Conclusion. Depression is the most common mental health disorder associated with chronic pain. It is extremely important to treat both depression and pain, in order to prevent the development of severe depression and chronic pain at an early stage. The integrated program at the level of primary health care is expected to have positive effects on both the physical and mental condition of patients. Cultural differences and ethnicity, which can significantly reduce the detection of depressive symptoms at the primary health care level, should certainly be taken into account.

Keywords: depression, anxiety, chronic non-malignant pain, ethnicity, primary health care

\section{Introduction}

Depression and anxiety are the most common mental disorders in the general population $(1,2)$ and the most common mental health disorder in patients in primary care (3-6). Although symptoms of depression are dominant in primary care patients, only a few patients discuss these symptoms directly with their physician. Two-thirds of primary care patients with depression also have somatic symptoms present (e.g., headache, or chronic pain), making it difficult to detect depression $(7,8)$.

If patients are not directly asked about their mood, they will omit information about depressive symptoms for a variety of reasons, including fear of stigmatization, belief that depression is beyond primary health care, belief that depression is not a "real" disease but a personal flaw. There are also concerns about medical records and data confidentiality, as well as concerns about prescribing antidepressant medications or referrals to a psychiatrist (9).

Among patients with chronic diseases, the annual prevalence of depression is significantly higher, about 25\% (10). The rate of depression may be particularly high in diseases of the central nervous system (e.g., stroke, traumatic brain injury, Parkinson's disease) (11-13), cardiovascular disorders $(14,15)$, cancer (16), and conditions involving immune and inflammatory mechanisms (e.g., systemic lupus erythematosus) (17). Risk factors for depression may be genetic, medical, environmental and social in nature, and they include: previous depressive episodes, family history, female gender, childbirth (i.e., postpartum depression), childhood trauma, stressful life events, poor social assistance, serious medical illness, dementia, drug abuse (18).

Patients with depressive syndrome may have mood swings, cognitive, neuro-vegetative, or somatic symptoms. Mood swings include sadness, emotional stress, emotional emptiness, or sometimes anxiety or irritability. Neuro-vegetative symptoms include loss of energy, changes in sleep, appetite, or weight. Some patients are more likely to have somatic symptoms (headache, pelvic pain, back pain, or other physical ailments), which can interfere with the diagnosis of depression. Populations in which somatic symptoms often predominate are pregnant women, the elderly, prisoners, members of other cultural nations, low-income patients, and patients with comorbidity of somatic symptoms and other diseases (7).

Risk screening options include two approaches. The first approach, recommended by the United States Preventive Services Task Force (USPSTF) is to monitor all patients during routine depression examinations and further evaluate those whose score is above a certain threshold (19). The second approach 
is more selective, known as case-finding, and evaluates only those patients whose clinical condition raises the suspicion of depression (20): insomnia, fatigue, chronic pain, recent life changes or stressors, good or poor health self-assessment, unexplained physical symptoms. Although the likelihood of depressive disorder increases by 1.5 to 3.5 -fold if a patient reports any of these symptoms, this targeted approach is only moderately more effective than routine screening and detects more patients with depressive disorder $(21,22)$.

Depression is widespread throughout the world, with a tendency to increase (23). A study conducted in ten countries: Brazil, Canada, Chile, the Czech Republic, Germany, Japan, Mexico, the Netherlands, Turkey, and the United States, shows that the prevalence of depression ranges from 3\% in Japan to $16 \%$ in the United States.The average range is from 8-12\% (24).

Data for Slovenia show that the prevalence of depression by gender is $17.4 \%$ in men and $14.6 \%$ in women. Major depressive disorder is more present in women $(6.5 \%)$ while it is significantly lower in men $(0.6 \%)$ (25). The lower rate of depression in some countries may be explained by cultural or genetic factors (26). For Croatia, there is no exact data for the prevalence of depression, but a survey was conducted for the capital of Croatia, Zagreb, where the prevalence of depression is about $2.2 \%$ (27).

Anxiety is closely related to depression, and these two most common mental health disorders are studied together. Generalized Anxiety Disorder (GAD) is characterized by excessive and persistent anxiety, which is difficult to control, and causes significant discomfort or damage, and lasts for at least six months. Other features include psychological symptoms of anxiety, such as irritability, and physical (or somatic) symptoms of anxiety, such as increased fatigue and muscle tension. Efficacy in the treatment of GAD includes psychological interventions such as cognitive-behavioral therapy and relaxation and pharmacotherapy. Epidemiological studies on nationally representative samples in the U.S. have found that generalized anxiety disorder (GAD) predominates from $5.1 \%(28,29)$ to $11.9 \%(30)$. A review of epidemiological studies in Europe (EU) estimates that $38.2 \%$ of the EU population suffers from a mental disorder each year. The most common disorders are anxiety disorders (14.0\%), insomnia (7.0\%), major depression (6.9\%) (31). In a study of patients in primary adult care in four Nordic countries, GAD rates ranged from 4.1 to $6.0 \%$ among men and from 3.7 to $7.1 \%$ among women (32). Anxiety disorder is about twice as common in women $(28,29)$ and probably the most common mental disorder in the elderly population $(31,33)$.

GAD is common among patients with "medically unexplained" chronic pain (34) and chronic physical illness (35). Although excessive and long-term anxiety is a feature of a generalized anxiety disorder (GAD), most patients have other symptoms present related to irritability, hyperactivity, and muscle tension. Many complain of poor sleep, fatigue, and difficulty relaxing. Headaches and pains in the neck, shoulders, and back are very common.

Chronic non-malignant pain is a major public health problem with a continuous increase in prevalence. Despite numerous studies, various pharmacological and non-pharmacological methods of treatment, and the establishment of pain treatment centers and clinics, chronic pain is still present in about $20 \%$ of the adult European population (36). Psychosocial factors, as well as individuals' reactions to pain, play an important role in the development of chronic pain (37). Studies show that both depression and anxiety are significantly more present in people with chronic pain $(23 \%)$, compared to those who do not have chronic pain (12\%) (38).

The objectives of the study were to investigate whether there is correlation between depression and anxiety and chronic non-malignant pain, their impact on treatment outcomes, and to investigate the association of chronic pain and depression among different ethnic groups.

\section{Methods}

\section{Sources of papers and search strategies}

A review of articles from the Medline database (via PubMed), on the topic of the relationship between depression, anxiety, ethnicity, chronic non-malignant pain, and primary health care.

The search strategy was a combination of terms that met the inclusion criteria, as possible methodologi- 
cal filters. For Boolean operators, the terms were combined with each other (and, or): depression and anxiety, and chronic non-malignant pain, and primary care or family practice, or primary level and ethnicity, depression and anxiety and chronic pain, primary health care or family medicine, or primary level and ethnicity). Search terms were keywords in English: depression, anxiety, chronicnon-malignant pain, primary care, ethnicity.

\section{The process of including and excluding papers in the review}

The analysis included papers according to the following criteria: all scientific papers in English, regardless of the methodology; papers related to the correlation between depression, anxiety, and chronic nonmalignant pain; papers which included primary care patients who were older than 18 years, members of ethnic groups and who were suffering from chronic non-malignant pain and at the same time had symptoms of depression and anxiety. As the research question was too broad, it needed to be narrowed down, so only papers published in the last five years (since 2011) were included in the review.

The excluded papers were the papers not written in English or the papers that did not include all the pre-defined criteria, as well as the papers published before 2011 that included patients under 18 years of age and the patients that did not have chronic non-malignant pain with concomitant symptoms of depression and anxiety.Paper titles that included depression, anxiety, chronic pain, primary health care, and ethnicity were reviewed.

The final analysis included 10 papers in English, published in 2011, that met all the given criteria: the correlation between depression, anxiety, and chronic non-malignant pain at the level of primary care.

\section{Methods of analysis}

Selected papers were analyzed in four steps. In the first step, the analysis included those articles whose titles corresponded to the selected keywords entered into the Medline database (via PubMed). In the second step, the papers published in the period 2011-2016 were analyzed. In the third step, abstracts of papers corresponding to the title and year of publication were analyzed. In the fourth step, a table was made with the overview of the included papers according to the title, goals, surveyed population, research method, and results. The articles were divided into groups, depending on the field of the topic they deal with (depression, anxiety, ethnicity, primary health care, and chronic non-malignant pain). Content analysis was performed. The correlation between depression, anxiety, and ethnicity in patients with chronic non-malignant pain, at the level of primary health care was researched. 


\section{Result}

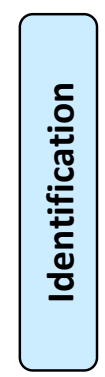

Records identified through Medline

(via PubMed) database searching

$$
(n=403)
$$
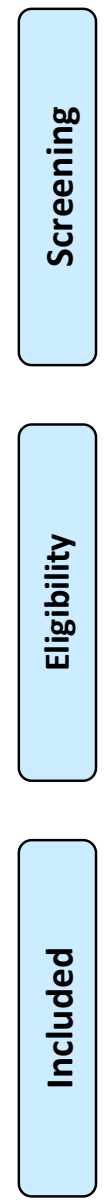

Additional records identified through other sources $(n=0)$
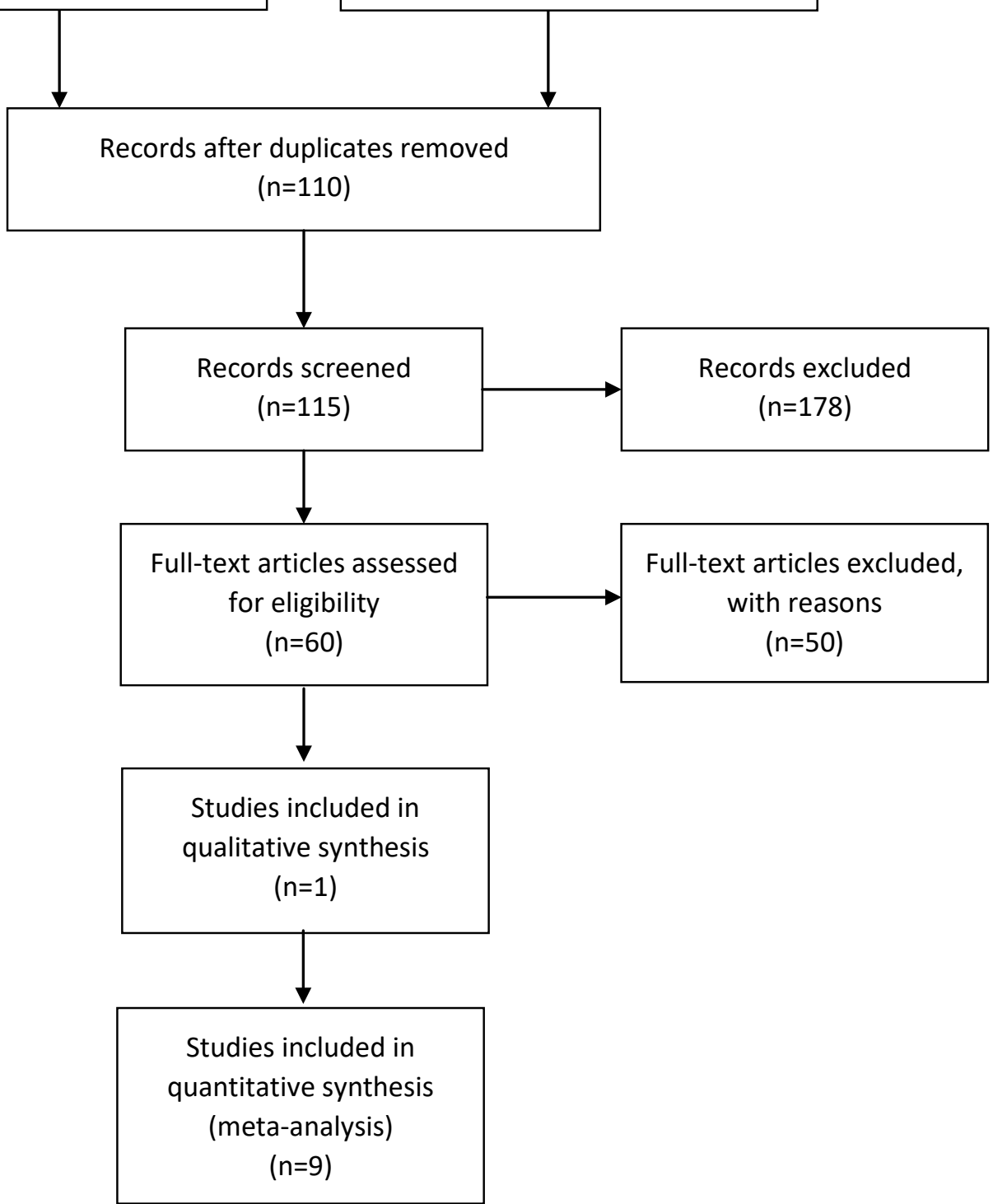

Figure 1. Flow chart of article search and selection process 
Table 1. Overview of the studies finally included

\begin{tabular}{|c|c|c|c|c|}
\hline Study & Aim & $\begin{array}{l}\text { Observed } \\
\text { population }\end{array}$ & Methods & Conclusion \\
\hline $\begin{array}{c}\text { Psychological } \\
\text { considerations in } \\
\text { the assessment and } \\
\text { treatment of pain in } \\
\text { neurorehabilitation } \\
\text { and psychological } \\
\text { factors predictive of } \\
\text { therapeutic response: } \\
\text { evidence and } \\
\text { recommendations } \\
\text { from the Italian } \\
\text { consensus } \\
\text { conference on pain in } \\
\text { neurorehabilitation } \\
\text { (39) }\end{array}$ & $\begin{array}{l}\text { 1. Identify } \\
\text { psychological factors } \\
\text { that are related, } \\
\text { or are predictive } \\
\text { of pain and are } \\
\text { a consequence } \\
\text { of neurological } \\
\text { diseases. } \\
\text { 2. Assess the impact } \\
\text { of these aspects } \\
\text { on the outcome of } \\
\text { neurorehabilitation. }\end{array}$ & $\begin{array}{l}\text { Patients with various } \\
\text { forms of chronic non- } \\
\text { malignant pain. }\end{array}$ & $\begin{array}{l}\text { PubMed database } \\
\text { search - a systematic } \\
\text { review of the } \\
\text { literature. }\end{array}$ & $\begin{array}{l}\text { Psychological factors } \\
\text { (depression, anxiety, } \\
\text { coping strategies, } \\
\text { excessive experience } \\
\text { of pain severity, } \\
\text { and beliefs about } \\
\text { pain) are associated } \\
\text { with pain. These } \\
\text { factors may predict } \\
\text { therapeutic response } \\
\text { to neurorehabilitation } \\
\text { interventions. }\end{array}$ \\
\hline $\begin{array}{l}\text { Understanding } \\
\text { the link between } \\
\text { depression and pain } \\
\text { (40) }\end{array}$ & $\begin{array}{l}\text { Elucidate the } \\
\text { relationship between } \\
\text { depression and pain. }\end{array}$ & $\begin{array}{l}\text { Patients with chronic } \\
\text { musculoskeletal pain. }\end{array}$ & $\begin{array}{l}\text { Searching databases } \\
\text { (MedLine and } \\
\text { PhysicINFO) found } \\
244 \text { articles including } \\
6 \text { reviews. }\end{array}$ & $\begin{array}{l}\text { There is a valid } \\
\text { reason to treat both } \\
\text { depression and pain, } \\
\text { in order to prevent } \\
\text { the development of } \\
\text { true depression and } \\
\text { chronic pain at an } \\
\text { early stage. }\end{array}$ \\
\hline $\begin{array}{l}\text { Efficacy and safety } \\
\text { of oral ketamine } \\
\text { versus diclofenac to } \\
\text { alleviate mild } \\
\text { to moderate } \\
\text { depression in } \\
\text { chronic pain } \\
\text { patients: Adouble- } \\
\text { blind, randomized, } \\
\text { controlled trial (41) }\end{array}$ & $\begin{array}{l}\text { Examine the safety } \\
\text { and efficacy of oral } \\
\text { ketamine versus } \\
\text { diclofenac, in } \\
\text { reducing symptoms } \\
\text { of mild to moderate } \\
\text { depression in } \\
\text { patients with chronic } \\
\text { pain. }\end{array}$ & $\begin{array}{l}\text { Patients with chronic } \\
\text { pain and symptoms } \\
\text { of mild to moderate } \\
\text { depression. }\end{array}$ & $\begin{array}{l}\text { A randomized, } \\
\text { controlled, double- } \\
\text { blind study, with two } \\
\text { groups of subjects. } \\
\text { (Original article) }\end{array}$ & $\begin{array}{l}\text { Oral ketamine is a } \\
\text { safe and effective } \\
\text { choice in improving } \\
\text { depressive symptoms } \\
\text { in patients with } \\
\text { chronic pain and } \\
\text { mild to moderate } \\
\text { depression. }\end{array}$ \\
\hline $\begin{array}{l}\text { Evaluation of a } \\
\text { multicomponent } \\
\text { programme for the } \\
\text { management of } \\
\text { musculoskeletal } \\
\text { pain and depression } \\
\text { in primary care: a } \\
\text { cluster-randomised } \\
\text { clinical trial (the } \\
\text { DROP study) (42) }\end{array}$ & $\begin{array}{l}\text { Examine whether } \\
\text { a new program } \\
\text { for an integrated } \\
\text { approach to chronic } \\
\text { musculoskeletal pain } \\
\text { and depression leads } \\
\text { to better results than } \\
\text { conventional care. }\end{array}$ & $\begin{array}{l}\mathrm{n}=330 \text { patients } \\
\text { aged } 18-80 \text { years, } \\
\text { with moderate } \\
\text { or severe } \\
\text { musculoskeletal pain } \\
(\geq 5), \text { for at least } 3 \\
\text { months and with } \\
\text { major depression } \\
\text { criteria (DSM-IV). }\end{array}$ & $\begin{array}{l}\text { Cluster randomized } \\
\text { controlled trial in } \\
\text { two groups: control } \\
\text { and the test group. } \\
\text { (Original article) }\end{array}$ & $\begin{array}{l}\text { Depression } \\
\text { and chronic } \\
\text { musculoskeletal pain } \\
\text { may benefit from an } \\
\text { integrated program } \\
\text { at the primary care } \\
\text { level. Positive effects } \\
\text { on both the physical } \\
\text { and mental condition } \\
\text { of the patient are } \\
\text { expected. }\end{array}$ \\
\hline $\begin{array}{l}\text { Anxiety, depression } \\
\text { and quality of life } \\
\text { in individuals with } \\
\text { phantom limb pain } \\
\text { (43) }\end{array}$ & $\begin{array}{l}\text { The aim of the } \\
\text { study was to assess } \\
\text { emotional factors, } \\
\text { such as anxiety and } \\
\text { depression, and the } \\
\text { quality of life of } \\
\text { people with chronic } \\
\text { pain after amputation } \\
\text { of a body part. }\end{array}$ & $\begin{array}{l}n=27 \text { patients aged } \\
18-80 \text { years. }\end{array}$ & $\begin{array}{l}\text { Descriptive, cross- } \\
\text { sectional study } \\
\text { with a quantitative } \\
\text { approach (semi- } \\
\text { structured interview) } \\
\text { (Original article) }\end{array}$ & $\begin{array}{l}\text { Anxiety is more } \\
\text { common at the } \\
\text { age of } 18-38, \text { and } \\
\text { depression is more } \\
\text { prevalent in older } \\
\text { patients aged } 60-80 \text {. }\end{array}$ \\
\hline
\end{tabular}




\begin{tabular}{|c|c|c|c|c|}
\hline Study & Aim & $\begin{array}{l}\text { Observed } \\
\text { population }\end{array}$ & Methods & Conclusion \\
\hline $\begin{array}{l}\text { Diagnosing } \\
\text { Depression in Chronic } \\
\text { Pain Patients: DSM- } \\
\text { IV Major Depressive } \\
\text { Disorder vs. Beck } \\
\text { Depression Inventory } \\
\text { (BDI) (44) }\end{array}$ & $\begin{array}{l}\text { The aim of this study } \\
\text { was to evaluate } \\
\text { the association } \\
\text { of somatic and } \\
\text { cognitive-emotional } \\
\text { items of the Beck } \\
\text { Depression Scale } \\
\text { with the diagnosis } \\
\text { of depression, } \\
\text { pain intensity, and } \\
\text { disability. }\end{array}$ & $\begin{array}{l}\mathrm{n}=100 \text { patients } \\
\text { with chronic pain }\end{array}$ & $\begin{array}{l}\text { Structured clinical } \\
\text { interview. (Research } \\
\text { article) }\end{array}$ & $\begin{array}{l}\text { Somatic, physical } \\
\text { symptoms factors } \\
\text { are associated with } \\
\text { major depressive } \\
\text { disorder (-MDD), } \\
\text { while a negative } \\
\text { self-image is not. } \\
\text { Insomnia and } \\
\text { weight loss were } \\
\text { not dependent on } \\
\text { the diagnosis of } \\
\text { depression.. }\end{array}$ \\
\hline $\begin{array}{l}\text { Impact of depression } \\
\text { and anxiety } \\
\text { on burden and } \\
\text { management of } \\
\text { episodic and chronic } \\
\text { headaches - a cross- } \\
\text { sectional multicentre } \\
\text { study in eight } \\
\text { Austrian headache } \\
\text { centres (45) }\end{array}$ & $\begin{array}{l}\text { The aim of this study } \\
\text { was to evaluate the } \\
\text { impact of depression } \\
\text { and anxiety on } \\
\text { the treatment } \\
\text { of episodic and } \\
\text { chronic headaches } \\
\text { in patients, in eight } \\
\text { Austrian headache } \\
\text { centers. }\end{array}$ & $\begin{array}{l}n=392 \text { patients with } \\
\text { chronic headache }\end{array}$ & $\begin{array}{l}\text { Cross-sectional } \\
\text { multicenter } \\
\text { examination. Original } \\
\text { article. }\end{array}$ & $\begin{array}{l}\text { Depression and } \\
\text { anxiety were more } \\
\text { common in subjects } \\
\text { with chronic than } \\
\text { episodic headaches } \\
\text { (64\% vs. } 41 \% \text {, p } \\
<0.0001) \text {. }\end{array}$ \\
\hline $\begin{array}{l}\text { Depression among } \\
\text { chronic pain patients } \\
\text { at Hospital Tengku } \\
\text { Ampuan Rahimah, } \\
\text { Klang (46) }\end{array}$ & $\begin{array}{l}\text { The aim of this study } \\
\text { was to investigate } \\
\text { the incidence of } \\
\text { depression and } \\
\text { depression-related } \\
\text { factors, in a sample } \\
\text { of patients with } \\
\text { chronic pain in } \\
\text { Malaysia. }\end{array}$ & $\begin{array}{l}\mathrm{n}=83 \text { clinically } \\
\text { diagnosed patients } \\
\text { with chronic pain. }\end{array}$ & $\begin{array}{l}\text { Cross-sectional } \\
\text { study. Original article. }\end{array}$ & $\begin{array}{l}\text { Nearly a third of } \\
\text { patients with chronic } \\
\text { pain, in this study, } \\
\text { have depression. } \\
\text { Depression is } \\
\text { significantly } \\
\text { associated with } \\
\text { the intensity and } \\
\text { duration of pain. }\end{array}$ \\
\hline $\begin{array}{l}\text { Selected aspects } \\
\text { of mental health of } \\
\text { elderly patients with } \\
\text { chronic back pain } \\
\text { treated in primary } \\
\text { care centers (47) }\end{array}$ & $\begin{array}{l}\text { The aim of this study } \\
\text { was to assess the } \\
\text { mental health of } \\
\text { patients with chronic } \\
\text { back pain treated in } \\
\text { primary care centers. }\end{array}$ & $\begin{array}{l}\mathrm{n}=100 \text { ( } 53 \text { patients } \\
\text { with chronic back } \\
\text { pain and } 47 \text { patients } \\
\text { without pain, in the } \\
\text { control group) }\end{array}$ & $\begin{array}{l}\text { The research was } \\
\text { conducted as an } \\
\text { anonymous screening } \\
\text { study. }\end{array}$ & $\begin{array}{l}\text { The study found that } \\
\text { mental health was } \\
\text { significantly poorer in } \\
\text { patients with chronic } \\
\text { back pain than in } \\
\text { healthy individuals. } \\
\text { A preliminary } \\
\text { assessment of } \\
\text { aspects of mental } \\
\text { health shows that } \\
\text { more attention } \\
\text { should be paid to } \\
\text { the rehabilitation of } \\
\text { patients with chronic } \\
\text { back pain treated } \\
\text { in primary care } \\
\text { practices. }\end{array}$ \\
\hline $\begin{array}{l}\text { Ethnic differences } \\
\text { in the association } \\
\text { between depression } \\
\text { and chronic pain: } \\
\text { cross-sectional } \\
\text { results from UK } \\
\text { Biobank (48) }\end{array}$ & $\begin{array}{l}\text { The aim of this study } \\
\text { was to investigate } \\
\text { chronic pain and } \\
\text { depression with } \\
\text { respect to ethnic } \\
\text { groups and to } \\
\text { examine whether } \\
\text { this association } \\
\text { differs, regardless of } \\
\text { possible factors. }\end{array}$ & $\begin{array}{l}n>500,000 \text { subjects } \\
\text { with chronic pain } \\
\text { and depression, aged } \\
40-70 \text { years, across } \\
\text { England, Scotland, } \\
\text { and Wales. }\end{array}$ & $\begin{array}{l}\text { Cross-sectional } \\
\text { study. Original article. }\end{array}$ & $\begin{array}{l}\text { Chronic pain and } \\
\text { depression differ } \\
\text { according to ethnic } \\
\text { groups. }\end{array}$ \\
\hline
\end{tabular}




\section{Discussion}

Musculoskeletal pain is one of the most common chronic non-malignant pain conditions, especially in patients in primary care, and is often associated with depression (42). Nearly one-third of patients with chronic pain also have depression (46). Of the many factors studied related to chronic non-malignant pain(depression, anxiety, excessive experience of pain severity, coping strategies and belief in pain), depression has been identified as a key factor and can be considered a predictor of secondary painful symptoms and conditions, such as, musculoskeletal pain, multiple sclerosis, etc. $(49,50)$. Of the demographic variables, the following are associated with depression: education level, age, and marital status, younger women, older men, the unemployed, and those who have been suffering from pain for a longer period of timehave a greater correlation with depression (51). Anxiety and depression also occur in patients who suffer from persistent chronic pain after limb amputation, at different levels (transfemoral, transtibial, transcarpal, and transhumeral). Research shows that anxiety is more common at a younger age, 18-36 years of age, while depression is more common in those of the older age group, 60-80 years of age (43).

In their study, Seed et al. (2015) particularly pointed out that higher pain intensity is significantly associated with the outcome of depression (46) and that depression significantly complicates effective pain management and affects quality of life, as confirmed by other authors (43 - 46). People who suffer from musculoskeletal pain and who are also depressed are twice as long on sick leave than those who suffer from pain but are not depressed $(52,53)$. In general, depression and anxiety reduce quality of life $(44,45)$, affect work status, resulting in reduced earnings, reduced career success, and a lack of understanding of the community. Social support, understanding of family, employers and colleagues have a strong impact on reducing anxiety and depression. It happens that patients avoid telling or complaining about experiencing pain such as a headache. Anxiety and depression have been shown to be more common in people with chronic headaches than in those with episodic headaches, and the ratio is $64 \%$ to $41 \%$ (45).
However, those with chronic headaches are more likely to seek medical help than those with episodic headaches (54). Examining the mental state in patients with chronic back pain, the results obtained show that mental health is significantly worse in patients with chronic non-malignant back pain than in healthy individuals. A preliminary assessment of aspects of mental health shows that more attention should be paid to the rehabilitation of patients with chronic back pain treated in primary care settings (47).

Assessing depression in chronic pain is challenging because somatic symptoms of depression and pain often overlap (44). Somatic symptoms are the ones that often lead to the diagnosis of depression, and if they were ruled out when diagnosing it, the rate of detected or diagnosed depressions would probably be drastically reduced (55). The consequences of undiagnosed depression are associated with a higher risk of suicide attempt in patients with chronic nonmalignant pain (56). By analyzing somatic and cognitive-emotional symptoms separately, it is possible to shed light on the occurrence of depression in chronic non-malignant pain (44). Although anxiety has been studied to a lesser extent than depression, it still has a high comorbidity rate with chronic pain conditions, and correlates with pain intensity, for example, it exacerbates headaches after traumatic brain injury $(57,58)$ and is also a predictor of chronic muscular bone pain after trauma (59).

In neurorehabilitation, effective pain management must certainly take into account both specific (e.g., anxiety, depression) and non-specific psychological factors of various illnesses (e.g., anger, fear, anger, avoidance, uncertainty), but also include the environment in which the person lives and family relationships as well (39). Therefore, there is a valid reason for the simultaneous treatment of both depression and pain, in order to prevent the development of severe depression at an early stage, but also chronic pain (40). It often happens that the focus is only on one of the symptoms, either chronic pain or depression, and in that case the other disease remains undetected. Both symptoms, depression and chronic non-malignant pain, need to be treated (39) thus increasing the successful outcome of treatment (40). The symptom of over-experiencing the severity of pain, which is also a factor associated with depression, should not be overlooked $(39,40)$. For example, if patients with chronic non-malignant pain, and concomitant mild to moderate depression, are given oral Ketamine therapy, the symptoms of depression improve (41). 
Patients who come to the doctor at primary health care differ in many aspects: age, gender, employment status, level of education, etc., and there are also differences in cultural and ethnic affiliation. These differences should certainly be taken into account, since the study by Nicholl et al (2015) showed that there are cultural barriers within the three ethnic groups that were included in the study (whites, Asians, and blacks) (48). In line with these differences, it is recommended to adapt the approach to patients of different ethnic groups. For example, population studies show that ethnic groups (Indians, Pakistanis, and Bangladeshis) in the United Kingdom (UK) go to the doctor more often than others for musculoskeletal pain, and this pain is spread in several places in the body (60). Regarding the correlation between depression and chronic pain, research by Nicholl et al (2015) shows that this association is present in all three ethnic groups studied (whites, Asians, and blacks), but is still somewhat more pronounced in the Asian and black ethnic groups. The majority of respondents had a history of depression, while the comorbidity of depression and chronic pain was present in $11 \%$ of respondents, and more often in ethnic minorities, especially in blacks as an ethnic group (48). On the other hand, mental health problems have been detected to a lesser extent in ethnic groups (Indians, Pakistanis, and Bangladeshis) by primary care physicians (60). Cultural differences and language barriers can be an obstacle to good health care, as well as ignorance of these differences by health professionals (48). With integrated programs at the primary health care level, positive effects can be expected on both the physical and mental condition of patients (42). It should certainly be emphasized that appropriate, valid treatment is of paramount importance, and above all adequate screening, i.e., early detection of depressive symptoms and risk groups, which certainly include people with chronic non-malignant pain.

\section{Conclusion}

Depression and anxiety are very common in patients suffering from chronic pain and are significantly associated with pain intensity. Liasion or consultative psychiatry should certainly be included in the treat- ment of patients with chronic pain for the purpose of diagnosing depression and anxiety. Oftentimes, the depressive disorder remains undetected and masked by physical symptoms. Primary care physicians are the first to be contacted by patients and this should be the site of the first level of screening. Good education of family physicians should also include knowledge of the mental disorders associated with most organic chronic diseases, especially those accompanied by pain. However, health professionals are often focused on only one disease and do not address other medical conditions. Optimal treatment at the primary care level should include a holistic approach and address concomitant conditions as well, since anxiety and depression along with chronic pain, often remain unrecognized and inadequately treated. This may be due to lack of time, cultural barriers, insufficient resources, or the skills of doctors. Early detection and treatment of psychological symptoms also result in a reduction in the secondary consequences of somatic disorders.

\section{References}

1. Kessler RC, Ormel J, Petukhova M, McLaughlin KA, Green JG, Russo LJ, et al. Development of lifetime comorbidity in the World Health Organization world mental health surveys. Arch Gen Psychiatry. 2011;68(1):90-100.

2. Wittchen HU, Kessler RC, Beesdo K, Krause P, Höfler $M$, Hoyer J. Generalized anxiety and depression in primary care: prevalence, recognition, and management. J Clin Psychiatry. 2002;63 Suppl 8:24-34.

3. Spitzer RL, Kroenke K, Williams JB. Validation and utility of a self-report version of PRIME-MD: the PHQ primary care study. Primary Care Evaluation of Mental Disorders. Patient Health Questionnaire. JAMA. 1999;282(18):1737-44.

4. Ansseau M, Dierick M, Buntinkx F, Cnockaert $P$, De Smedt J, Van Den Haute $M$, et al. High prevalence of mental disorders in primary care. J Affect Disord. 2004;78(1):49-55.

5. Linzer M, Spitzer R, Kroenke K, Williams JB, Hahn S, Brody $D$, et al. Gender, quality of life, and mental disorders in primary care: results from the PRIME-MD 1000 study. Am J Med. 1996;101(5):526-33.

6. Roca M, Gili M, Garcia-Garcia M, Salva J, Vives M, Garcia Campayo J, et al. Prevalence and comorbidity of common mental disorders in primary care. J Affect Disord. 2009;119(1-3):52-8. 
7. Tylee A, Gandhi P. The importance of somatic symptoms in depression in primary care. Prim Care Companion J Clin Psychiatry. 2005;7(4):167-76.

8. Simon GE, VonKorff M, Piccinelli M, Fullerton C, Ormel J. An international study of the relation between somatic symptoms and depression. N Engl J Med. 1999;341(18):1329-35.

9. Bell RA, Franks P, Duberstein PR, Epstein RM, Feldman $M D$, Fernandez y Garcia $E$, et al. Suffering in silence: reasons for not disclosing depression in primary care. Ann Fam Med. 2011;9(5):439-46.

10. Meader N, Mitchell AJ, Chew-Graham C, Goldberg D, Rizzo M, Bird V, Kessler D, et al. Case identification of depression in patients with chronic physical health problems: a diagnostic accuracy meta-analysis of 113 studies. Br J Gen Pract. 2011;61(593):e808-20.

11. Robinson RG. Poststroke depression: prevalence, diagnosis, treatment, and disease progression. Biol Psychiatry. 2003;54(3):376-87.

12. McDonald WM, Richard IH, DeLong MR. Prevalence, etiology, and treatment of depression in Parkinson's disease. Biol Psychiatry. 2003;54(3):363-75.

13. Jorge RE, Robinson RG, Moser D, Tateno A, Crespo-Facorro B, Arndt S. Major depression following traumatic brain injury. Arch Gen Psychiatry. 2004;61(1):42-50.

14. Huffman JC, Smith FA, Blais MA, Beiser ME, Januzzi JL, Fricchione GL. Recognition and treatment of depression and anxiety in patients with acute myocardial infarction. Am J Cardiol. 2006;98(3):319-24.

15. Whooley MA. Depression and cardiovascular disease: healing the broken-hearted. JAMA. 2006;295(24):2874-81.

16. Reiche EM, Nunes SO, Morimoto HK. Stress, depression, the immune system, and cancer. Lancet Oncol. 2004;5(10):617-25.

17. Hanly JG, Fisk JD, McCurdy G, Fougere L, Douglas JA. Neuropsychiatric syndromes in patients with systemic lupus erythematosus and rheumatoid arthritis. J Rheumatol. 2005;32(8):1459-6.

18. Karg RS, Bose J, Batts KR, Forman-Hoffman VL, Liao D, Hirsch E, Pemberton MR, Colpe LJ, Hedden SL. Past Year Mental Disorders among Adults in the United States: Results from the 2008-2012 Mental Health Surveillance Study. 2014. In: CBHSQ Data Review. Rockville (MD): Substance Abuse and Mental Health Services Administration (US); 2012-.

19. Siu AL; US Preventive Services Task Force (USPSTF), Bibbins-Domingo K, Grossman DC, Baumann LC, Davidson KW, Ebell M, et al. Screening for Depression in Adults: US Preventive Services Task Force Recommendation Statement. JAMA. 2016;315(4):380-7.

20. Jackson JL, O'Malley PG, Kroenke K. Clinical predictors of mental disorders among medical outpatients. Validation of the "S4" model. Psychosomatics. 1998;39(5):431-6.
21. Conde MV, Williams JW Jr, Mulrow CD. Targeting depression interviewing: an exercise in diagnostic reasoning. J Gen Intern Med. 1998;13(4):262-5.

22. Callahan CM, Hendrie HC, Dittus RS, Brater DC, Hui SL, Tierney WM. Depression in late life: the use of clinical characteristics to focus screening efforts. J Gerontol. 1994;49(1):M9-14.

23. Bromet $E$, Andrade $L H$, Hwang I, Sampson NA, Alonso J, de Girolamo G, et al. Cross-national epidemiology of DSM-IV major depressive episode. BMC Med. 2011;9:90.

24. Andrade L, Caraveo-Anduaga J], Berglund P, Bijl RV, De Graaf R, Vollebergh W, et al. The epidemiology of major depressive episodes: results from the International Consortium of Psychiatric Epidemiology (ICPE) Surveys. Int J Methods Psychiatr Res. 2003;12(1):3-21.

25. King M, Nazareth I, Levy G, Walker C, Morris R, Weich S, et al. Prevalence of common mental disorders in general practice attendees across Europe. Br J Psychiatry. 2008;192(5):362-7.

26. Weissman MM, Bland RC, Canino G], Faravelli C, Greenwald $S$, Hwu HG, et al. Cross-national epidemiology of major depression and bipolar disorder. JAMA. 1996;276(4):293-9.

27. Stojanović-Spehar S, Blazeković-Milaković S, AmerlSakić V, Kolić N, Supe S. Depression prevalence and estimation of psychosocial parameters within adult population in city of Zagreb. Psychiatr Danub. 2009;21(4):497-507.

28. Wittchen HU, Zhao S, Kessler RC, Eaton WW. DSM-III-R generalized anxiety disorder in the National Comorbidity Survey. Arch Gen Psychiatry. 1994;51(5):355-64.

29. Kessler RC, Berglund $P$, Demler 0 , Jin R, Merikangas $K R$, Walters EE. Lifetime prevalence and age-of-onset distributions of DSM-IV disorders in the National Comorbidity Survey Replication. Arch Gen Psychiatry. 2005;62(6):593-602.

30. Kessler RC, Gruber M, Hettema JM, Hwang I, Sampson $\mathrm{N}$, Yonkers KA. Co-morbid major depression and generalized anxiety disorders in the National Comorbidity Survey follow-up. Psychol Med. 2008;38(3):365-74.

31. Wittchen HU, Jacobi F, Rehm J, Gustavsson A, Svensson $M$, Jönsson $B$, et al. The size and burden of mental disorders and other disorders of the brain in Europe 2010. Eur Neuropsychopharmacol. 2011;21(9):65579.

32. Munk-Jørgensen $P$, Allgulander C, Dahl AA, Foldager $L$, Holm M, Rasmussen I, et al. Prevalence of generalized anxiety disorder in general practice in Denmark, Finland, Norway, and Sweden. Psychiatr Serv. 2006;57(12):1738-44.

33. Lenze EJ. Anxiety disorders in the elderly. In: Textbook of Anxiety Disorders, 2nd ed, Stein DJ, Hollander E, Rothbaum BO. (Eds), American Psychiatric Publishing, Inc, Washington, DC 2010. p.651. 
34. Beesdo K, Hoyer J, Jacobi F, Low NC, Höfler M, Wittchen HU. Association between generalized anxiety levels and pain in a community sample: evidence for diagnostic specificity. J Anxiety Disord. 2009;23(5):684-93.

35. Allgulander C. Morbid anxiety as a risk factor in patients with somatic diseases. A review of recent findings. Mind and brain. J Psychiatry. 2010;1:11-9.

36. Wijnhoven HA, de Vet HC, Picavet HS. Explaining sex differences in chronic musculoskeletal pain in a general population. Pain. 2006;124(1-2):158-66.

37. Bair MJ, Wu J, Damush TM, Sutherland JM, Kroenke K. Association of depression and anxiety alone and in combination with chronic musculoskeletal pain in primary care patients. Psychosom Med. 2008;70(8):8907.

38. Von Korff M, Moore JC. Stepped care for back pain: activating approaches for primary care. Ann Intern Med. 2001;134(9 Pt 2):911-7.

39. Castelnuovo G, Giusti EM, Manzoni GM, Saviola D, Gatti A, Gabrielli S, et al. Psychological considerations in the assessment and treatment of pain in neurorehabilitation and psychological factors predictive of therapeutic response: evidence and recommendations from the Italian consensus conference on pain in neurorehabilitation. Front Psychol. 2016;7:468.

40. Linton SJ, Bergbom S. Understanding the link between depression and pain. Scand J Pain. 2011;2(2):47-54.

41. Jafarinia M, Afarideh M, Tafakhori A, Arbabi M, Ghajar $A$, Noorbala $A A$, et al. Efficacy and safety of oral ketamine versus diclofenac to alleviate mild to moderate depression in chronic pain patients: A double-blind, randomized, controlled trial. J Affect Disord. 2016;204:1-8.

42. Aragonès $E$, López-Cortacans G, Caballero A, Piñol JL, Sánchez-Rodríguez E, Rambla C, et al. Evaluation of a multicomponent programme for the management of musculoskeletal pain and depression in primary care: a cluster-randomised clinical trial (the DROP study). BMC Psychiatry. 2016;16:69.

43. Padovani MT, Martins MR, Venâncio A, Forni JE. Anxiety, depression and quality of life in individuals with phantom limb pain. Acta Ortop Bras. 2015;23(2):10710.

44. Knaster P, Estlander AM, Karlsson H, Kaprio J, Kalso E. Diagnosing Depression in Chronic Pain Patients: DSMIV Major Depressive Disorder vs. Beck Depression Inventory (BDI). PLoS One. 2016;11(3):e0151982.

45. Zebenholzer K, Lechner A, Broessner G, Lampl C, Luthringshausen $G$, Wuschitz $A$, et al. Impact of depression and anxiety on burden and management of episodic and chronic headaches - a cross-sectional multicentre study in eight Austrian headache centres. J Headache Pain. 2016;17:15.

46. Seed HF, Hazli Z, Perumal M, Azlin B. Depression among chronic pain patients at Hospital Tengku Ampuan Rahimah, Klang. Med J Malaysia. 2015;70(5):303-6.
47. Cabak A, Dabrowska-Zimakowska A, Tomaszewski P, Łyp M, Kaczor R, Tomaszewski W, et al. Selected aspects of mental health of elderly patients with chronic back pain treated in primary care centers. Med Sci Monit. 2015;21:3327-33.

48. Nicholl BI, Smith DJ, Cullen B, Mackay D, Evans J, Anderson J, et al. Ethnic differences in the association between depression and chronic pain: cross sectional results from UK Biobank. BMC Fam Pract. 2015;16:128.

49. Wasserman RA, Brummett CM, Goesling J, Tsodikov A, Hassett AL. Characteristics of chronic pain patients who take opioids and persistently report high pain intensity. Reg Anesth Pain Med. 2014;39(1):13-7.

50. Harrison AM, Silber E, McCracken LM, Moss-Morris R. Beyond a physical symptom: the importance of psychosocial factors in multiple sclerosis pain. Eur J Neurol. 2015;22(11):1443-52.

51. Averill PM, Novy DM, Nelson DV, Berry LA. Correlates of depression in chronic pain patients: a comprehensive examination. Pain. 1996;65(1):93-100.

52. Currie SR, Wang J. Chronic back pain and major depression in the general Canadian population. Pain. 2004;107(1-2):54-60.

53. Druss BG, Rosenheck RA, Sledge WH. Health and disability costs of depressive illness in a major U.S. corporation. Am J Psychiatry. 2000;157(8):1274-8.

54. Blumenfeld AM, Varon SF, Wilcox TK, Buse DC, Kawata $A K$, Manack A, et al. Disability, HRQol and resource use among chronic and episodic migraineurs: results from the International Burden of Migraine Study (IBMS). Cephalalgia. 2011;31(3):301-15.

55. Wilson KG, Mikail SF, D'Eon JL, Minns JE. Alternative diagnostic criteria for major depressive disorder in patients with chronic pain. Pain. 2001;91(3):227-34.

56. Tang NK, Crane C. Suicidality in chronic pain: a review of the prevalence, risk factors and psychological links. Psychol Med. 2006;36(5):575-86.

57. Ligthart L, Gerrits MM, Boomsma DI, Penninx BW. Anxiety and depression are associated with migraine and pain in general: an investigation of the interrelationships. J Pain. 2013;14(4):363-70.

58. Weyer Jamora C, Schroeder SC, Ruff RM. Pain and mild traumatic brain injury: the implications of pain severity on emotional and cognitive functioning. Brain Inj. 2013;27(10):1134-40.

59. Castillo RC, Wegener ST, Heins SE, Haythornthwaite JA, MacKenzie EJ, Bosse MJ; LEAP Study Group. Longitudinal relationships between anxiety, depression, and pain: results from a two-year cohort study of lower extremity trauma patients. Pain. 2013;154(12):2860-66.

60. Choudhury Y, Bremner SA, Ali A, Eldridge S, Griffiths C], Hussain I, et al. Prevalence and impact of chronic widespread pain in the Bangladeshi and White populations of Tower Hamlets, East London. Clin Rheumatol. 2013;32(9):1375-82. 


\section{POVEZANOST DEPRESIJE I ANKSIOZNOSTI KOD BOLESNIKA S KRONIČNOM NEMALIGNOM BOLI}

\section{Sažetak}

Uvod. Dvije trećine pacijenata primarne zdravstvene zaštite $s$ depresijom ima prisutne i somatske simptome, čineći otkrivanje depresije težom. Primarna zdravstvena zaštita prva je razina probira za depresiju, a rano otkrivanje ključno je za uspjeh liječenja. Anksioznost također ima visoku stopu komorbiditeta s kroničnim bolnim stanjima. Generalizirani anksiozni poremećaj (GAD) čest je među pacijentima $S$ "medicinski neobjašnjivom" kroničnom boli i kroničnim fizičkim bolestima te je i prediktor kronične mišićno-koštane boli nakon traume. Pripadnost različitim etničkim skupinama i činjenica da liječnici primarne zdravstvene zaštite nepoznaju te razlike mogu biti prepreka u dobroj zdravstvenoj skrbi, prije svega ranom prepoznavanju simptoma depresije.

Cilj. Cilj ovog predloženog, sistematičnog rada bio je izvući zaključke iz empirijskog istraživanja koje se bavi procesima uključenima u ispitivanje depresije, anksioznosti i kronične nemaligne boli. Istraživačko pitanje za ovaj pregledni rad bilo je ispitati povezanost depresije i anksioznosti s kroničnom nemalignom boli. Cilj je bio ispitati ulogu primarne zdravstvene zaštite u prepoznavanju, prevenciji i liječenju depresije i anksioznosti kod bolesnika s kroničnom nemalignom boli te postoji li razlika u povezanosti depresije, anksioznosti i kronične nemaligne boli s obzirom na etničku pripadnost.

Metode. Metode za identifikaciju studije izvedene su iz baze podataka Medline (via PubMed). U analizu su uključeni svi znanstveni radovi na engleskom jeziku, bez obzira na metodologiju, objavljeni od 2011. koji se odnose na povezanost depresije, anksioznosti i kronične nemaligne boli, koji obuhvaćaju populaciju pacijenata iz primarne zdravstvene zaštite starijih od 18 godina koji boluju od kronične nemaligne boli i istodobno imaju prisutne simptome depresije i anksioznosti ili su pripadnici etničkih skupina. Pronađeno je 403 članka, originalnih i preglednih radova, od kojih je nakon detaljnog čitanja odabrano 10 koji zadovoljavaju uključujuće kriterije za potrebe ovog pregleda.

Rezultati. Depresija i anksioznost značajno su prisutnije kod osoba s kroničnom boli (23 \%) u odnosu na one koji ih nemaju (12\%). Najčešća je mišićnokoštana kronična bol, pri čemu trećina pacijenata ima depresiju. Depresija i anksioznost značajno su povezane s intenzitetom i trajanjem boli. Kronična bol i depresija razlikuju se i s obzirom na etničke skupine, pri čemu kulturalne razlike i jezična barijera mogu biti prepreka u ranom otkrivanju depresije.

Zaključak. Depresija je najčešća smetnja mentalnog zdravlja koja je povezana s kroničnom boli. Od iznimne je važnosti liječenje i depresije i boli, kako bi se u ranoj fazi spriječio razvoj teže depresije i kronične boli. Od integriranog programa na razini primarne zdravstvene zaštite očekuju se pozitivni učinci i na fizičko i na psihičko stanje pacijenata.Svakako treba uzeti u obzir kulturološke razlike i etničku pripadnost, koje na razini primarne zdravstvene zaštite mogu značajno smanjiti otkrivanje simptoma depresije.

Ključne riječi: depresija, anksioznost, kronična nemaligna bol, etnička pripadnost, primarna zdravstvena zaštita 